\title{
New Technologies in Educational Solutions in the Field of STEM: The Use of Online Communication Services to Manage Teamwork in Project-Based Learning Activities
}

\author{
https://doi.org/10.3991/ijet.v16i24.25227 \\ Menglin Fang ${ }^{1,2(凶)}$, Abdygali Jandigulov ${ }^{3}$, Zoya Snezhko ${ }^{4}$, \\ Leonid Volkov 5 , Olesya Dudnik ${ }^{4}$ \\ ${ }^{1}$ Minxi Vocational \& Technical College, Fujian, China \\ ${ }^{2}$ Lomonosov Moscow State University, Moscow, Russian Federation \\ ${ }^{3}$ L.N. Gumilyov Eurasian National University, Nur-Sultan, Republic of Kazakhstan \\ ${ }^{4}$ Sechenov First Moscow State Medical University (Sechenov University), Moscow, Russian \\ Federation \\ ${ }^{5}$ Financial University under the Government of the Russian Federation, Moscow, Russian \\ Federation \\ menglinfang 44 @rambler.ru, Wendy.Betania@campus.mccd.edu
}

\begin{abstract}
STEM education as an innovative paradigm of education is being rapidly introduced into the curricula of higher educational institutions. The research is devoted to the study of the capabilities of online communication services for managing teamwork aimed at the development and implementation of innovative investment projects in the STEM education environment. An innovative concept of a distance learning course - Designing investment projects in the field of health care and recreation - is suggested based on organizational principles. The online communication services such as Mirapolis Virtual Room, Moodle and Microsoft Teams implemented into the educational interaction program made it possible to create a high-quality real-time elearning environment. The online course was tested by 200 students. The results of the experiment confirmed the effectiveness of the use of online communication services and platforms in the development of professional practical experience within the educational concept of STEM. Students appreciated the high level of the innovative component in team interaction programs $(98 \%)$, as well as, in the approaches to cooperation with business entities (95\%); $91 \%$ of students noted the high level of quality of the educational content, pedagogical (84\%), technological (92\%) and conceptual (78\%) innovative value of the educational product. Taking a course that is based on the STEM model had a dramatic impact on the development of the key competencies of the 21 st century. The study can be of interest to teachers who are looking for effective pedagogical models that can be easily adapted to the needs of the business environment and the generation of students of the new digital era.
\end{abstract}

Keywords - digital learning platforms; innovative educational product; investment project; online communication services; project-based learning activity; STEM education. 


\section{Introduction}

The development of ethical, intercultural and critical thinking to ensure the thoughtful application of exponentially evolving technologies is an educational requirement $\mathrm{m}$ within the framework of the rapid development of the digital economy on a global scale. A well-planned program aimed at the implementation of digital technologies in educational processes can ensure the quality development of a qualified workforce possessing knowledge and skills needed for a harmonious interaction with digital changes [1].

In the current context of the digital economy development, the tasks of higher educational institutions are to teach students the highest level of efficiency, creativity and entrepreneurship. Due to the fact that innovative solutions in education will become much-in-demand the new first-class currency of the future, public goals in the process of teaching and learning must be of the highest importance [2]. Innovation is becoming a sought-after university asset creating new models of higher education for the global economy, which are based on the optimal combination of business orientation, entrepreneurial skills, leadership qualities, ethics and values, crowdsourcing of ideas and projects. Innovation in the education system combined with the philosophy of entrepreneurship, experiential learning and modern IT technologies has the potential to improve the quality of life and prosperity of nations. Encouraging entrepreneurship and collaboration with the private sector, promoting diversity and inclusion, and exploring the relationship between technology and society, create a new quality of university proposals for higher education [3]. In this context, STEM, as an innovative approach to education that combines four disciplines: science, technology, engineering and mathematics, is important for training the new generation of learners and is an effective pedagogical methodology aimed at the development of high-quality professional competencies [4]. The widespread use of this technique and its active research over the past ten years can be explained by the need to improve the quality of technical education and the fast pace of technological progress. Currently, STEM education has become a popular methodological bases for studying natural science disciplines in most countries of Europe, a number of Asian states, Australia and the USA [5].

Conceptually, STEM education is based on problem solving that considers concepts and processes from the point of view of science and mathematics while incorporating collaboration and engineering design methodologies involving appropriate technologies. STEM education is being transformed from traditional teacher-centered learning to active student-centered learning [6]. STEM education aims to train students for the development of science and technology and teach them to solve problems [7].

STEM expands the ability to critically reflect on and explore each discipline in more detail through an interdisciplinary lens. STEM relies on a scientific paradigm that focuses on experimental approaches to scientific problems with an emphasis on fundamental knowledge and skills as educational tools [8]. STEM education is based on the integrated teaching of STEM disciplines in the context of real problems and in accordance with the activities of real professionals. In this respect, it is important for 
learners to deal with problems simulated based on real production processes, which includes the formation of problems similar to those faced by professionals operating in STEM fields, and requires the application of more than one STEM discipline (all of them when possible) to solve them. STEM education is capable of building 21 st century skills, including collaboration and teamwork, problem solving, creative thinking, social responsibility, critical thinking, exploration and interactive use of technology [9]. A STEM curriculum not only teaches students to deal with activities requiring specific knowledge but also to apply the acquired skills in different contexts. Consequently, students with relevant skills, knowledge and experience in STEM are in high demand in both traditional STEM fields and other job sectors [10].

A science, technology, engineering, and math (STEM) education improves students' academic achievement in maths and science, strengthens student attitudes towards subjects, and enhances higher-level thinking skills. The main advantages of STEM education include integrated teaching of "topics" rather than subjects, application of scientific and technical knowledge in simulated real environments, development of high-level creative and critical thinking, team interaction skills in the process of active learning, an increase in students' intellectual self-sufficiency and selfconfidence, formation of a constructive relationship between education and career, preparation of students for the production of innovative technological solutions in the professional sphere, as well as the development of interest in technical disciplines [11].

The purpose of the research is to study the capabilities of online communication services for managing teamwork aimed at the development and implementation of innovative investment projects in the STEM education environment.

The following tasks have been set:

- to propose a conceptual model for the development and management of educational innovations within the concept of STEM education;

- based on the model, to develop the concept of a distance learning course - Designing investment projects in the field of health care and recreation;

- to implement online communication services such as Mirapolis Virtual Room, Moodle and Microsoft Teams into the educational interaction program;

- test the online course among students of Sechenov First Moscow State Medical University (Sechenov University), Lomonosov Moscow State University, Financial University under the Government of the Russian Federation, and L.N. Gumilyov Eurasian National University.;

- at the end of the course, to interview students and identify the contribution of educational practice and the concept of the course to their future professional activities;

- interview experts and study their opinions on the relevance of investment projects developed by students for tourism, health care and recreation industries, as well as the degree of their innovative value in the context of digital transformation. 


\section{Methods and materials}

\subsection{Theoretical Framework}

As the world becomes a more digital place, the educational sector is increasingly saturated with digital games, applications, websites, social media, and learning environments. It is becoming obvious that digital platformization is a specific process that changes the meaning, opportunities, and potential functions of education.

Advances in educational technology have provided a variety of innovative solutions to support student learning and offered unique opportunities for complex integrated STEM learning environments. For example, a learning environment can be extended with immersive and interactive technologies (simulation and play-based approaches) to facilitate the study of multiple subjects at the same time. Technology can be used to support collaboration and communication by involving remote subject experts into the learning process to provide hands-on learning experiences. Technology can be used to increase student engagement and motivation, expand the experience, and accelerate learning by serving as an additional learning resource. Technology-assisted collaboration and communication foster active learning. Immersive and interactive technologies such as augmented reality (AR) and virtual reality (VR) can give students an immersive experience that will foster their understanding and participation in STEM subjects. Technology can facilitate learning of STEM subjects and help students integrate different disciplinary ideas; for example, when using simulation. Therefore, it is very important to combine technology with integrated STEM education and learn to use it to support student learning and solve educational problems [12].

Online learning platforms play an important role in modern education. Online learning can meet the needs of both active and passive learning. It aims to provide students with complete knowledge that can be accessed anywhere and anytime [13]. The network platform is a programmable digital architecture designed to organize interaction between participants - not only end-users but also corporate and government organizations. Digital learning platforms are increasingly investing in new, unique and specialized digital educational resources that make educational practices accessible, clear and effective through the deployment and implementation of innovative pedagogical concepts [14].

The development of innovative digital technologies has led to the application of modeling and visualization $(\mathrm{S} \& \mathrm{~V})$ in various fields as an effective virtual interactive tool [15]. In order to ensure successful implementation of STEM education, it is important to include relevant project-based learning activities and integrate them into the process of engineering design, which should focus on the needs of consumers rather than the imagination of designers, which poses a number of additional challenges to students. To meet consumer needs, students must learn to analyze demand and critically assess it in order to produce effective solutions. 3D printing technologies can be used to support modeling in the engineering design process [16]. Repetitive modeling in STEM-based design activities with the use of 3D printers improves student imagi- 
nation and is effective in developing students' interest in the application of technology in the process of creating educational projects [17].

In STEM education, Intelligent Tutoring Systems (ITS) are gaining popularity; these are designed to create an educational experience that can be customized according to the needs of the student, and include simulations, such as demonstrating a specific area of a concept, which allows learners to solve tasks and reproduce a real situation [18].

In modern educational practice, augmented reality (AR) is widely used to support learning in the field of science, technology, engineering and mathematics (STEM) [19]. The main advantage of introducing AR technologies into educational practices is the ability to visualize hard-to-imagine objects turning them into three-dimensional models, which makes it easier for students to understand abstract and complex information. AR users can select color, opacity, angle, etc. The use of augmented reality technologies particularly contributes to the development of students' abstract thinking, as well as the implementation of educational tasks aimed at transforming theoretical content into real projects [20]. Unlike AR technologies, which can overlay information about the object being studied, VR provides a three-dimensional environment that learners can interact with. AR and VR technologies empower education and learning and provide new dynamic experiences that immediately engage learners. AR and VR allow students to interact and collaborate by manipulating virtual objects. These modes of interaction can help them understand concepts, master skills, and complete various tasks or procedures [21].

\subsection{Research design}

The concept of the learning course - Designing investment projects in the field of health care and recreation - is based on the model of development and management of educational innovations in STEM-education, which functionally combines various elements (Fig. 1).

In the process of developing the concept of the learning course, the following organizational principles were given particular emphasis (Fig. 2).

The innovative course was implemented from January to June 2021 within the framework of a joint educational project and involved students of Sechenov First Moscow State Medical University (Sechenov University), Lomonosov Moscow State University, Financial University under the Government of the Russian Federation, and L.N. Gumilyov Eurasian National University. There were 200 students, 20 experts, 10 moderators and 4 course curators who participated in the study (Table 1). 


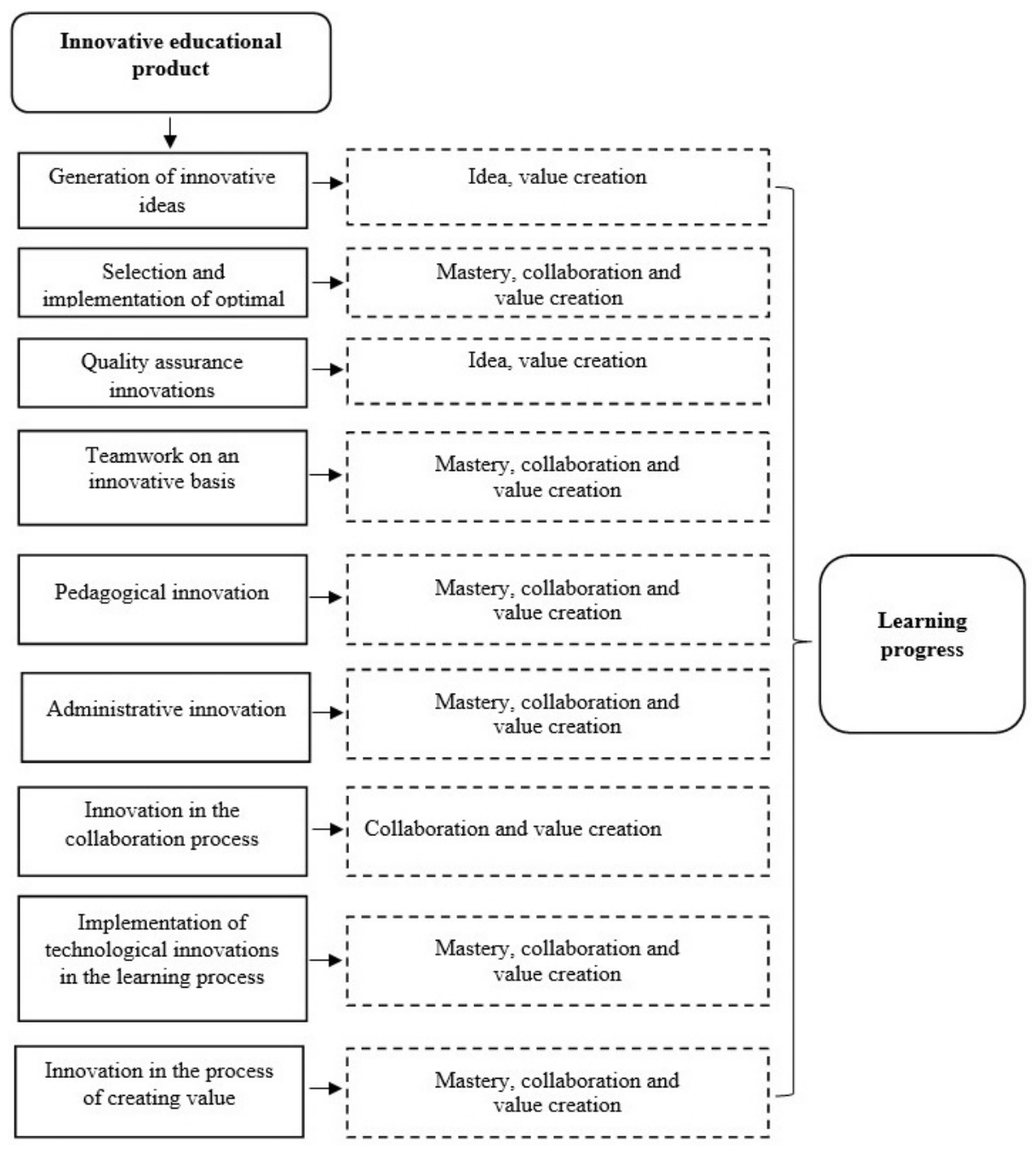

Fig. 1. A conceptual model for the development and management of educational innovations within the concept of STEM education * own development based on [3] 


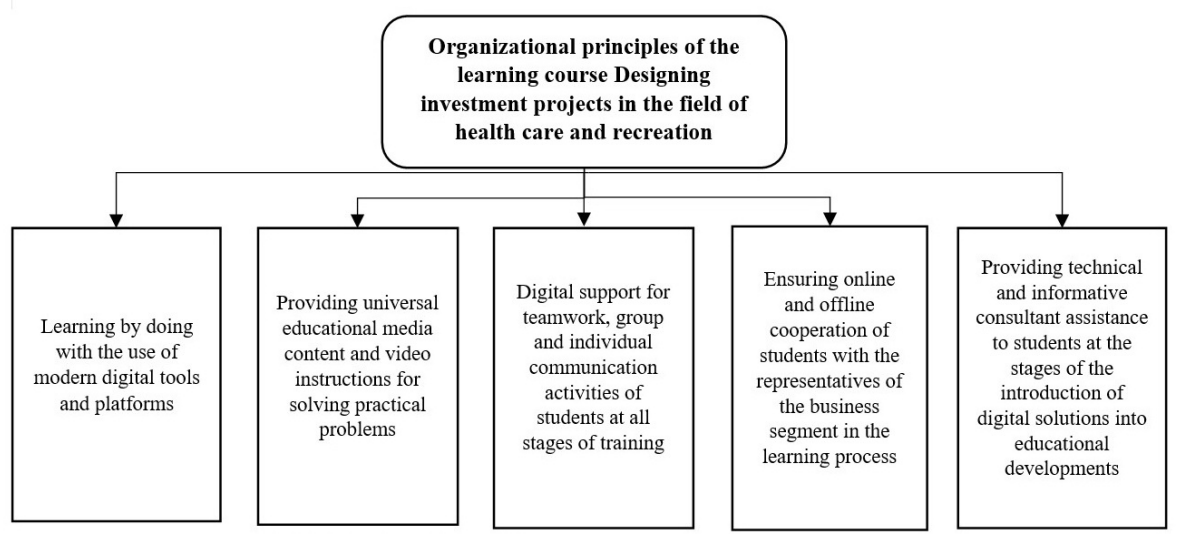

Fig. 2. Organizational principles of the learning course *own development

Table 1. Experiment participants - students

\begin{tabular}{|c|c|c|c|}
\hline $\begin{array}{l}\text { Number of } \\
\text { students }\end{array}$ & Training programs & Faculty & University \\
\hline 7 & 38.03.02 Management & $\begin{array}{l}\text { Medicine of the Future } \\
\text { International School }\end{array}$ & \multirow{4}{*}{$\begin{array}{l}\text { Sechenov First Moscow } \\
\text { State Medical University } \\
\text { (Sechenov University) }\end{array}$} \\
\hline 5 & 31.05.05 General medicine & General Medicine Faculty & \\
\hline 8 & 32.05.01 Preventive medicine & General Medicine Faculty & \\
\hline 4 & $\begin{array}{l}\text { 09.03.02 Information systems and } \\
\text { technologies }\end{array}$ & $\begin{array}{l}\text { Medicine of the Future } \\
\text { International School }\end{array}$ & \\
\hline 9 & 43.04 .02 Tourism & \multirow[t]{3}{*}{ Geography Faculty } & \multirow{13}{*}{$\begin{array}{l}\text { Lomonosov Moscow } \\
\text { State University }\end{array}$} \\
\hline 6 & $\begin{array}{l}\text { 05.04.00 Ecology and nature man- } \\
\text { agement }\end{array}$ & & \\
\hline 11 & 05.04.00 Climate and environment & & \\
\hline 4 & $\begin{array}{l}\text { 02.04.01 Digital technology and } \\
\text { artificial intelligence }\end{array}$ & \multirow{2}{*}{$\begin{array}{l}\text { Faculty of Computational } \\
\text { Mathematics and Cyber- } \\
\text { netics }\end{array}$} & \\
\hline 4 & $\begin{array}{l}\text { 02.04.02 Fundamental informatics } \\
\text { and information technologies }\end{array}$ & & \\
\hline 5 & $\begin{array}{l}06.04 .01 \text { Genomics and human } \\
\text { health }\end{array}$ & Biology Department & \\
\hline 9 & $\begin{array}{l}51.04 .01 \text { Digital technologies in } \\
\text { culture }\end{array}$ & \multirow[t]{2}{*}{ Philosophy faculty } & \\
\hline 7 & $\begin{array}{l}42.04 .01 \text { Advertising and public } \\
\text { relations }\end{array}$ & & \\
\hline 10 & 38.04.02 Marketing & \multirow[t]{3}{*}{ Faculty of Economics } & \\
\hline 13 & $\begin{array}{l}\text { 38.04.02 Business development } \\
\text { management }\end{array}$ & & \\
\hline 9 & 38.04.02 Innovation management & & \\
\hline 8 & 42.04.05 Media communications & Faculty of Journalism & \\
\hline 5 & 38.04.03 Personnel management & $\begin{array}{l}\text { Higher School of Contem- } \\
\text { porary Social Sciences }\end{array}$ & \\
\hline
\end{tabular}


Paper-New Technologies in Educational Solutions in the Field of STEM: The Use of Online Communi..

\begin{tabular}{|c|c|c|c|}
\hline 7 & 27.04.05 Innovation & $\begin{array}{l}\text { Higher School of Man- } \\
\text { agement and Innovation }\end{array}$ & \\
\hline 7 & 38.04.03 Personnel management & $\begin{array}{l}\text { Faculty of Social Sciences } \\
\text { and Mass Communication }\end{array}$ & \multirow{5}{*}{$\begin{array}{l}\text { Financial University } \\
\text { under the Government of } \\
\text { the Russian Federation }\end{array}$} \\
\hline 6 & 38.04.02 Management & $\begin{array}{l}\text { Institute of Online Educa- } \\
\text { tion }\end{array}$ & \\
\hline 12 & 38.04.05 Business informatics & $\begin{array}{l}\text { Faculty of Information } \\
\text { Technology and Big Data } \\
\text { Analysis }\end{array}$ & \\
\hline 11 & $\begin{array}{l}43.04 .02 \text { Tourism sustainable devel- } \\
\text { opment of the hospitality and tourism } \\
\text { industry }\end{array}$ & $\begin{array}{l}\text { Faculty of Economics and } \\
\text { Business }\end{array}$ & \\
\hline 9 & $\begin{array}{l}42.04 .01 \text { Advertising and public } \\
\text { relations }\end{array}$ & $\begin{array}{l}\text { Faculty of Social Sciences } \\
\text { and Mass Communication }\end{array}$ & \\
\hline 6 & 6B05304 Physics (natural sciences) & $\begin{array}{l}\text { Physical and Technical } \\
\text { Faculty }\end{array}$ & \multirow[t]{4}{*}{$\begin{array}{l}\text { L.N. Gumilyov Eurasian } \\
\text { National University }\end{array}$} \\
\hline 7 & 5B020100 Philosophy & Faculty of Social Sciences & \\
\hline 6 & 6B03102 International relations & $\begin{array}{l}\text { Faculty of International } \\
\text { Relations }\end{array}$ & \\
\hline 5 & 5V030100 Jurisprudence & Faculty of Law & \\
\hline \multicolumn{4}{|c|}{ Total: 200 people } \\
\hline
\end{tabular}

The experts were the owners and managers of businesses in the tourism, health and recreation segment, whose professional interests were aimed at finding and implementing innovative projects in the field of health, tourism and recreation in order to diversify business proposals and develop private entrepreneurship (Table 2).

Table 2. Experiment participants - experts

\begin{tabular}{|c|l|l|}
\hline Number of experts & \multicolumn{1}{|c|}{ Economic activity } & \multicolumn{1}{c|}{ Professional interests } \\
\hline 3 & Sanatorium-and-health-resort sector & $\begin{array}{l}\text { Search and implementation of } \\
\text { innovative projects in the segment of } \\
\text { health improvement, tourism and } \\
\text { recreation in order to diversify } \\
\text { business proposals and develop } \\
\text { private entrepreneurship }\end{array}$ \\
\hline 3 & SPA business & \\
\hline 2 & Service e-commerce & \\
\hline 2 & Hospitality business & \\
\hline 5 & Catering business & \\
\hline 3 & Recreation and sports tourism & \\
\hline 1 & Beauty industry & \\
\hline Total: 200 people & Medical tourism & \\
\hline
\end{tabular}

The concept of the learning course - Designing investment projects in the field of health care and recreation - was developed by 4 curators - teachers of the Sechenov First Moscow State Medical University (Sechenov University), Lomonosov Moscow State University, Financial University under the Government of the Russian Federation, and L.N. Gumilyov Eurasian National University.

There were 10 course moderators who provided informative and consultant assistance to students at all stages of training, ensured productive discussions and the ex- 
change of ideas, provided mentoring support in the process of implementing technological solutions into practical developments.

The educational interaction of course participants took place via online communication services such as Mirapolis Virtual Room, Moodle and Microsoft Teams (Table 3).

Table 3. Technologies used in the course

\begin{tabular}{|c|c|}
\hline Online service & Characteristics \\
\hline Mirapolis Virtual Room (n.d.) & $\begin{array}{l}\text { A universal digital communication platform for audio and video } \\
\text { conferencing that allows up to } 1500 \text { people with no time restriction. } \\
\text { The service capabilities include: } \\
\text { - designing virtual room interface; } \\
\text { - setting the quality of sound and image while broadcasting video } \\
\text { online; } \\
\text { - access to the chat during a video conference, the ability to export the } \\
\text { chat archive to Excel; } \\
\text { - active interaction of video conference participants; } \\
\text { - distribution of roles and rights of participants during the event; } \\
\text { - grouping video conference participants in the catalog at the discre- } \\
\text { tion; } \\
\text { - setting up participant registration options; } \\
\text { - uploading participant lists from XLS files; } \\
\text { - customizing notifications through HTML markup; } \\
\text { - recording the event and converting it to MP4 format; } \\
\text { - collaborative document viewing during video broadcast (doc, xls, } \\
\text { ppt, pdf); } \\
\text { - creating polls, saving results, statistics of responses; } \\
\text { - creating analytical reports based on the results of the meetings. }\end{array}$ \\
\hline Moodle (n.d.) & $\begin{array}{l}\text { A learning management system that allows users to upload any type } \\
\text { of educational content: text (including PDF and XLS), images, } \\
\text { presentations, videos and tests. The online service provides an oppor- } \\
\text { tunity for mobile learning in real time. }\end{array}$ \\
\hline Microsoft Teams (n.d.) & $\begin{array}{l}\text { An online service for group online interactions within the framework } \\
\text { of joint project development, document editing, which allows users to } \\
\text { immediately contact colleagues and exchange relevant information, } \\
\text { schedule meetings, etc. The service capabilities are as follows: } \\
\text { - an unlimited number of free virtual meetings, video and audio calls } \\
\text { involving up to } 100 \text { people. } \\
\text { - the duration of online meetings is up to } 60 \text { minutes; } \\
\text { - } 10 \text { GB of team cloud storage and } 2 \text { GB of personal storage; } \\
\text { - it is available on Windows, Mac, iOS and Android devices. }\end{array}$ \\
\hline
\end{tabular}

The MirapolisVirtualRoom platform was used to hold online group discussions between students and course experts which raised the issues and prospects of industry development, as well as to interview the participants.

The Moodle platform was used by the curators to provide students with the educational media content and instructions for the execution of the project.

Microsoft Teams was used to promote teamwork to implement joint investment projects.

At the end of the course, the moderators interviewed students in order to identify the contribution of educational practice and the concept of the course to their future professional activities. In addition, experts were interviewed and their opinions on the 
relevance of investment projects developed by students for tourism, health care and recreation industries, as well as the degree of their innovative value in the context of digital transformation were studied.

\subsection{Research limitations}

Due to the fact that the experiment was conducted in order to describe the application of the STEM approach in the process of forming professional competencies of students of higher educational institutions, the limitations of the study are associated, first of all, with the subjective assessment of the results obtained. Conceptually, the expert group consisted of the representatives of the business environment, who focused on the search for creative ideas and new opportunities for their implementation; therefore, the limitation of expert assessment is due to the lack of a professional approach to assessing the quality of investment design. In this regard, in further studies, it is advisable to expand the expert group with professionals in the field of finance and investment, investment analysts and auditors.

\section{$2.4 \quad$ Ethical issues}

The anonymity of the participants and confidentiality of personal data were guaranteed. The research participants were informed about the goals and objectives of the study and gave their written consent to participate in the experiment; they were also informed about their right to refuse participation at any stage of the experiment.

\section{Results and discussion}

Training was carried out in a distance format with the use of the digital capabilities of online communication services. The learning activity of students within the framework of the course was based on the "learn by doing" principle and focused on the development of investment projects that are potentially in demand in the business environment. The structure of the course consisted of 9 stages (Fig. 3).

Stage 1,2,3, and 8 of the course and the survey of the participants at the end of training were conducted with the help of the technological capabilities of the Mirapolis Virtual Room platform, which is a universal digital communication platform for organizing video conferences, webinars, e-learning, workshops and other types of online events. The Mirapolis Virtual Room service provided an opportunity to develop an original virtual room interface for holding online discussions, and also facilitated the active participation of students, experts, curators, and moderators in the discussions. The main advantages of the online service are the interface of the virtual room; audio and video conferencing, in-meeting chat, setting up roles and access rights, sharing presentations and videos, interacting with participants, working with meeting files, screen sharing, polling, branding, preparation and post-processing of meetings, reports, recording, notifications, registration for events, data import and integration [22]. 


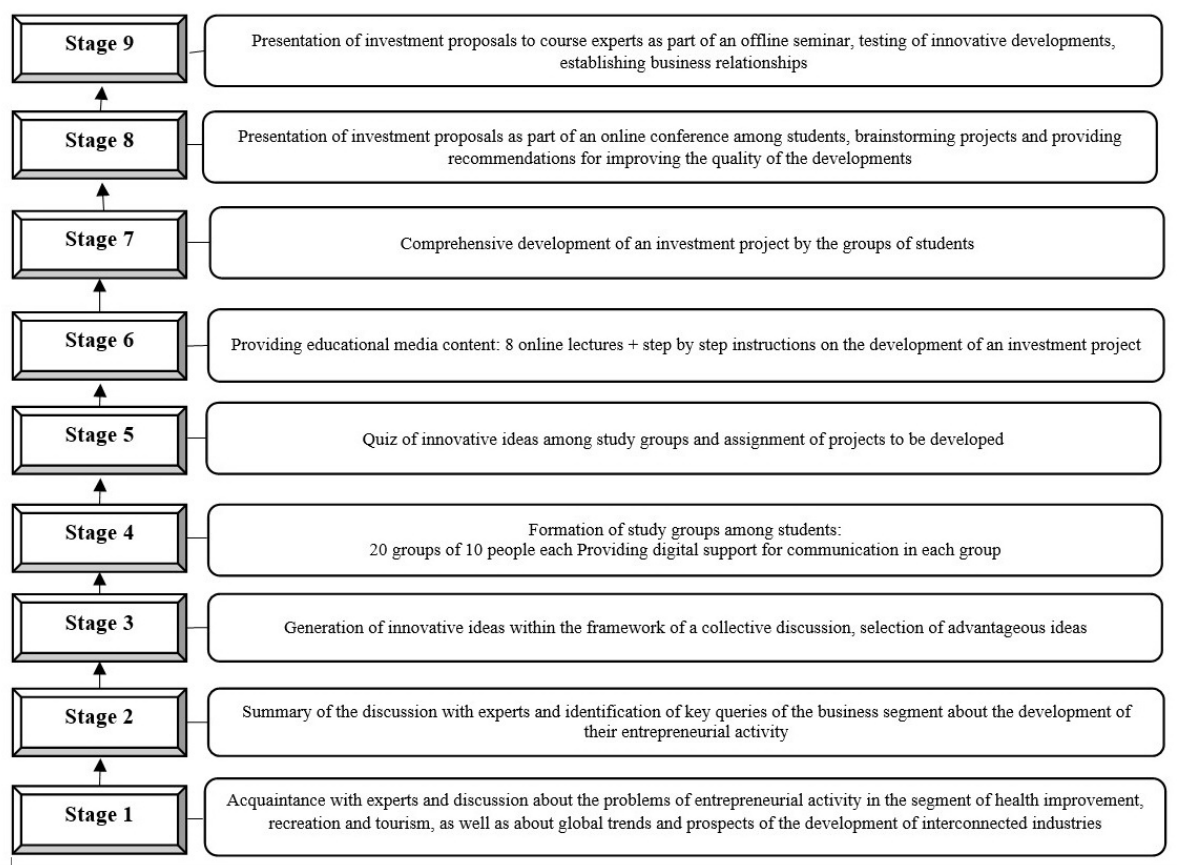

Fig. 3. The structure of learning activities proposed by the Designing investment projects in the field of health care and recreation course *own development

Online lectures were delivered with the help of the Moodle platform. The educational content was divided into 8 thematic units; each unit contained a video instruction on the development of the investment project parts (Fig. 4).

Teamwork aimed at the development of investment projects was based on the Microsoft Teams service, which made it possible to conduct online meetings of study group members, plan joint activities, work together on a project in real-time, hold a collective discussion about proper completion of project tasks, have informal conversations, make edits, as well as work together on shared files and develop materials.

At the final stage of the course, students had an opportunity to present their investment proposals to the course experts as part of an offline seminar, demonstrate the capabilities of innovative developments, and establish business relations with potential employers.

Analyzing the results of the learning activities of students, the experts appreciated the high level of innovation and technological completeness of investment projects developed by the students in the learning process showing a high level of interest in intellectual creativity. The experts confirmed the originality and relevance of educational developments and outlined the prospects of their implementation in professional activities. 


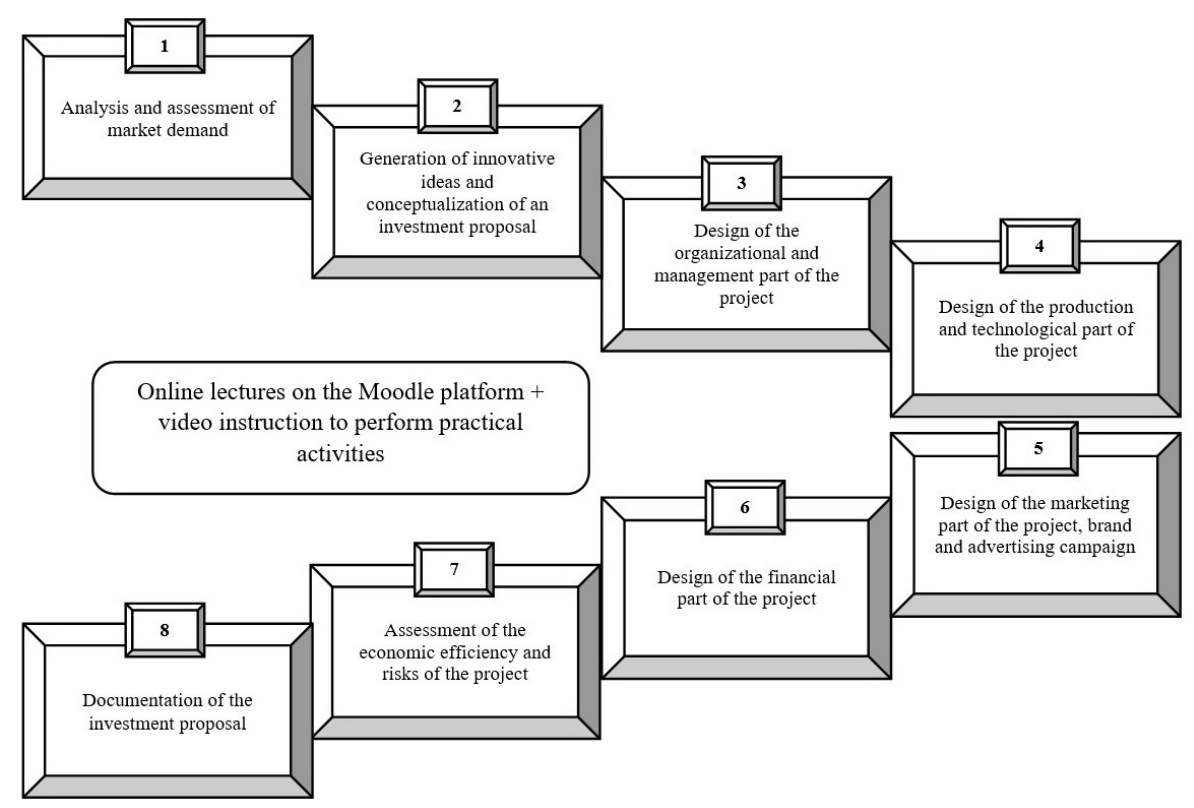

Fig. 4. Thematic structure of educational media content *own development

The results of the survey of students (participants in the experiment) made it possible to determine the contribution of the learning experience gained in the learning process. According to $97 \%$ of students, learning by doing allowed them to qualitatively consolidate the knowledge and skills acquired before completing the course and master new professional competencies in terms of partner interactions, generation of ideas, their deployment and implementation.

According to $91 \%$ of students, project-based activities strengthened their desire to participate in group practices and promoted their high-quality self-expression in groups. Due to the fact that the study groups for the development of investment projects were formed according to the principles of diversification of specialties, gender balance, and the system of separation of powers, $95 \%$ of the participants associated the high quality of educational developments with a rational approach to the formation of project working groups. Most students noted that working on an assignment in a distance format with the use of the technological capabilities of the Microsoft Teams service was quite effective, comfortable and productive; $99 \%$ of students confirmed the feasibility of implementing online communication services in group educational interactions aimed at collaborative learning.

According to $89 \%$ of students, the course has dramatically developed their professional skills, the ability to collaborate and create valuable intellectual products.

The students were asked to evaluate the course on seven criteria on a 12-point scale (Table 4). 
Paper-New Technologies in Educational Solutions in the Field of STEM: The Use of Online Communi...

Table 4. Assessment of the degree of the innovative component of the training course

\begin{tabular}{|l|c|c|c|}
\hline \multicolumn{1}{|c|}{ Criteria } & $\begin{array}{c}\text { Low level of } \\
\text { innovation } \\
(\mathbf{1 - 6 )}\end{array}$ & $\begin{array}{c}\text { Average level of innova- } \\
\text { tion } \\
\text { (7-9) }\end{array}$ & $\begin{array}{c}\text { High level of } \\
\text { innovation } \\
(\mathbf{1 0 - 1 2})\end{array}$ \\
\hline conceptual innovation & - & $22 \%$ & $78 \%$ \\
\hline pedagogical innovation & - & $16 \%$ & $84 \%$ \\
\hline technological innovation & - & $8 \%$ & $92 \%$ \\
\hline administrative support innovation & - & $32 \%$ & $68 \%$ \\
\hline team interaction program innovation & - & $2 \%$ & $98 \%$ \\
\hline $\begin{array}{l}\text { innovation of the program of coopera- } \\
\text { tion with business entities }\end{array}$ & - & $5 \%$ & $95 \%$ \\
\hline educational content innovation & - & $9 \%$ & $91 \%$ \\
\hline
\end{tabular}

*own development

In addition, the students assessed their personal progress in the development of the key competencies of the 21 st century (Fig. 5).

A successful STEM program uses integrated approaches that include a variety of educational activities [25]. The effective implementation of STEM activities is closely related to pedagogical initiatives that seek to find new educational strategies and support student motivation by combining scientific and technological knowledge [26]. Although integrated STEM initiatives have become popular in recent years and there has been an increase in research on the positive impact of STEM education, these integrated learning approaches have not become the pedagogical norm. This is due to the fact that a number of problems that can be divided into pedagogical and technical ones arise in the implementation of an integrated STEM program. Teachers are faced with the challenge of acquiring the technical or scientific knowledge needed for the proper integration of content. The assistance to technology teachers is crucial for science teachers. Moreover, it is important to provide teachers with an opportunity to share their views, experiences and approaches to STEM education as a way to implement best practices in integrated STEM education [27]. In STEM teacher training, demand-driven learning strategies, reflective practice and collaboration, which helps to fully develop pedagogical competencies that are reflective and flexible in various educational settings and situations, should be highlighted [28].

A study of the Romanian education system offered a number of recommendations and actions regarding the use of technology in STEM education. First, there is a need to increase the use of digital resources and tools in STEM learning activities to promote in-depth learning and acquisition of the 21st century skills (problem solving, analysis, assessment and critical thinking, collaboration, creativity). Secondly, there is a need to expand access and interaction with certain scientists in the field of STEM by visiting institutes and research centers for innovations development, as well as by conducting videoconferences, webinars, etc. Last but not least, it is important to emphasize the need for a systematic and well-organized approach to expanding teachers' rights and capabilities in STEM education in the process of integrating digital technologies into the educational practice. This can be translated into a STEM teacher training strategy that should be based on transformational learning that influences genuine STEM learning and career [29]. 


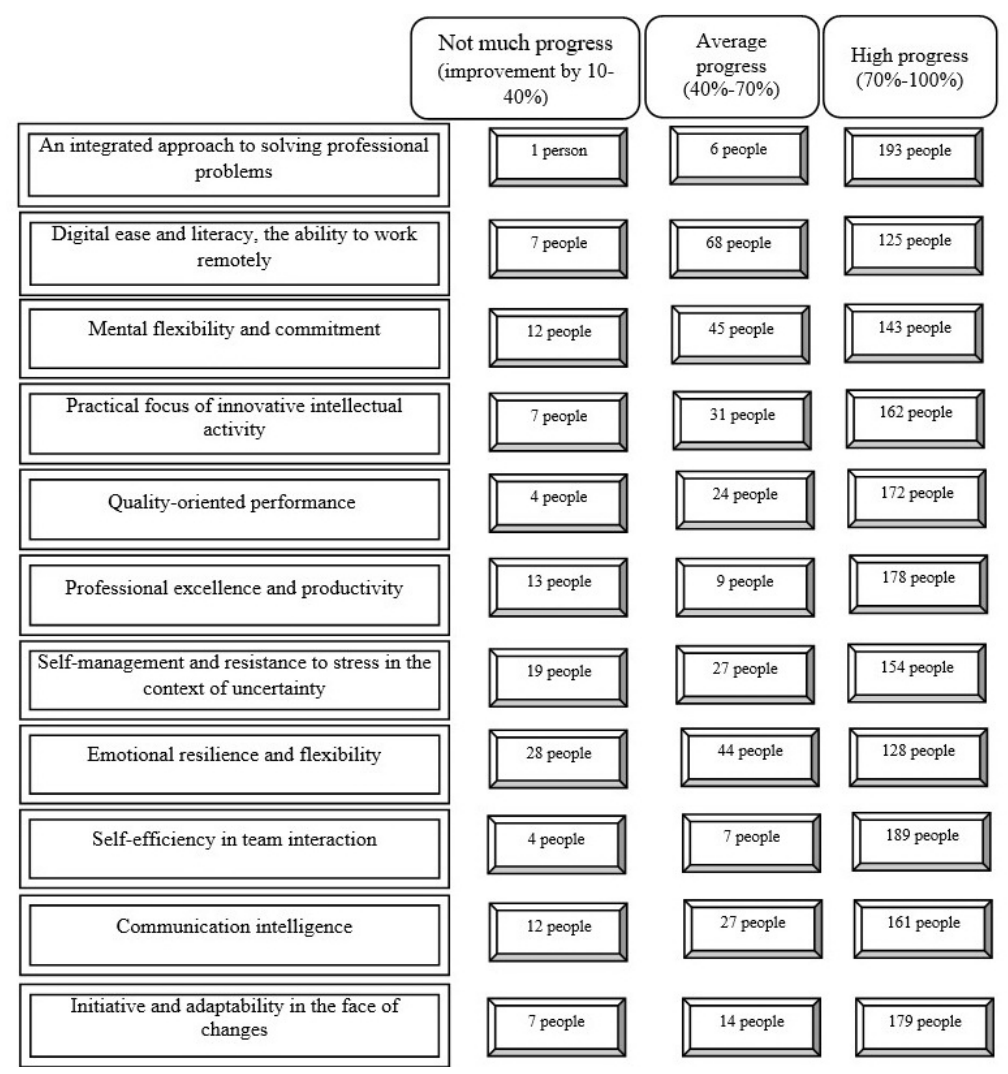

Fig. 5. The impact of the approach embedded in the course on the acquisition of the key competencies of the 21 st century *own development

An important factor for the successful implementation of STEM education is the efforts of stakeholders who share a common vision of STEM. The technology of STEM curriculum design can be improved by addressing better practices and increased opportunities for feedback during learning. The level of knowledge and experience in the field of pedagogical concepts should be improved. Specific teacher development training can be organized to combine achievements related to different disciplines and solve them within a general subject or problem [30]. For example, a teaching and learning scholarship (SoTL) plays a vital role in ensuring the continuous improvement of STEM pedagogy reflecting the changing needs of students, as well as the increased opportunities offered by technological innovations [31]. To maximize the benefits of innovative pedagogy and make learning more student-centered, it will be necessary to expand the reach of highly qualified educators and free up their time for planning, teamwork, and individual counseling of students at all stages of learning. It is necessary to implement flexible scheduling to meet the educational needs of students, as well as introduce effective counseling models to provide social, emotional and academic support to students in building effective learning interactions [32]. 
Understanding the Nature of Science, Technology, Engineering and Mathematics (NOSTEM) can serve as a powerful tool for developing various aspects of science students' education helping learners to better understand scientific content and maintain a positive attitude towards science and the scientific approach. The integration of a number of subjects, including STEM subjects, into education should become the main driving force behind national intellectual development. The integration of all four STEM disciplines is a major up-to-date trend in education that makes learning more meaningful for students. As a result, students can better understand the value of their studies and apply knowledge in everyday life, which can lead to greater employment opportunities in the future and, in turn, stimulate the national economy [33].

In the context of STEM training in American educational institutions, a new innovative approach -STREAM (STEM + Arts + Recreation) - is popularized; it is aimed at expanding practical learning experience. STREAM uses unique aspects of art and recreation in addition to STEM education. The study found that in addition to art, recreation not only improves physical fitness, but also supports mental health and cognitive function. This combination produces a synergistic effect in STEM education. The results of the study confirmed that recreation can be used as an effective tool for teaching STEM concepts. Teachers and researchers should consider any use of fun activities to teach STEM concepts more effectively. For example, STEM educators can partner with recreation professionals to create unique cultural and recreational activities that can facilitate learning of STEM concepts [10]. STEM education can also promote symbiotic relationship between professional cultures and areas of knowledge, motivate students, and contribute to solving social and global problems [34].

A study of the extent of simultaneous openness and innovation of online higher education at Athabasca University (AU), Canada, has shown that one online course cannot be completely open to diverse student groups and it cannot be made technologically innovative by integrating cutting-edge technologies. In addition, being pedagogically innovative due to increased interactivity between students while maintaining the same level of flexibility ensured by an independent learning model seems to be a very challenging task [35].

A study devoted to rethinking of STEM education in China as praxis challenges the technical framework of STEM education and relis on the theoretical curriculum reconceptualization in the field of training programs. STEM education is being reinterpreted as praxis in its life, ethical and historical dimensions involving the use of vital, detailed, and rich STEM experience structured ethically and linked to history. Researchers have concluded that instead of importing models of STEM education practice from the West, it is advisable to encourage Chinese STEM teachers to use their own educational and scientific developments within the framework of vertical (for example, historical) and horizontal (for example, internationalization) interaction with various internal and external changes at the stages of the development of international STEM education [8]. 


\section{Conclusions}

The innovative concept of the course - Designing investment projects in the field of health care and recreation - was based on the model of the development and management of educational innovations, which functionally combined various elements, such as generation of innovative ideas, selection, and implementation of optimal ideas, quality assurance innovations, teamwork on an innovative basis, pedagogical innovation, administrative innovation, collaborative innovation, development innovation, value-creation innovation. The conceptual framework of the model determined the course focus on the generation of innovative ideas, expertise, collaboration, and value creation. Functionally, the educational interaction between the course participants was ensured via Mirapolis Virtual Room, Moodle, and Microsoft Teams, which confirmed their effectiveness and feasibility at the stages of the implementation of learning activities in the context of online learning. Students appreciated the high level of the innovative component of the educational product, in particular the conceptual (78\%), pedagogical (84\%) and technological (92\%) content of the course, the originality of educational content $(91 \%)$, as well as the innovative value of the team interaction program $(98 \%)$ and approaches to cooperation with business entities $(95 \%)$.

The experts appreciated the high level of innovation and technological completeness of investment projects developed by the students having confirmed the relevance of educational developments in the business environment.

According to students, the course activities had a dramatic impact on the development of their key professional competencies. Students achieved good progress in the following indicators: an integrated approach to solving professional problems (193 people), self-efficiency in team interaction (189 people), initiative and adaptability in the face of changes (179 people), professional excellence and productivity (178 people), quality-oriented performance (172 people), practical focus of innovative intellectual activity (162 people), communication intelligence (161 people), self-management and resistance to stress in the context of uncertainty (154 people), mental flexibility and purposefulness (143 people), emotional resilience (128 people), digital ease and literacy, the ability to work remotely (125 people).

The experiment confirmed the effectiveness of distance interactions of students based on online services in the process of joint project activities, which opens the prospect of further research on the implementation of innovative digital solutions in international education cooperation programs within the framework of the STEM model.

\section{Acknowledgment}

Menglin Fang was supported by Minxi Vocational \& Technical College Project: Fzjx21b-048 "Research on curriculum system's linkage of the major in preschool education among secondary vocational, higher vocational and undergraduate under the counterpart enrollment mode". 


\section{References}

[1] Yusuf, B., Walters, L.M., Sailin, S.N. (2020). Restructuring Educational institutions for growth in the Fourth Industrial Revolution (4IR): A systematic review. International Journal of Emerging Technologies in Learning, 15(3): 93-109. https://doi.org/10.3991/ijet.v15i03.11849

[2] Jandigulov, A.R., Tlepbai, Q. (2018). Distance learning of discrete mathematics. In International conference. Barnaul, Russian Federation, pp. 238-240.

[3] Sharma, M.K., Sharma, R.C. (2021). Innovation framework for excellence in higher education institutions. Global Journal of Flexible Systems Management, 22(2): 141-155. https://doi.org/10.1007/s40171-021-00265-x

[4] Nguyen, T.P., Nguyen, T.H., Tran, T.K. (2020). STEM education in secondary schools: Teachers' perspective towards sustainable development. Sustainability, 12: 8865. https://doi.org/10.3390/su12218865

[5] Liu, Z.Y., Chubarkova, E., Kharakhordina, M. (2020). Online technologies in STEM education. International Journal of Emerging Technologies in Learning, 15(15): 20-32. https://doi.org/10.3991/ijet.v15i15.14677

[6] Hasanah, U. (2020). Key definitions of STEM education: Literature review. Interdisciplinary Journal of Environmental and Science Education, 16(3): e2217. https://doi.org/10.29333/ijese/8336

[7] Sujarwanto, E., Ibrahim, M. (2019). Attitude, knowledge, and application of STEM owned by science teachers. In Journal of Physics: Conference Series (Vol. 1417, No. 1). IOP Publishing, pp. 012096. https://doi.org/10.1088/17426596/1417/1/012096

[8] Ma, Y. (2021). Reconceptualizing STEM education in China as praxis: A curriculum turn. Sustainability, 13: 4961. https://doi.org/10.3390/su13094961

[9] Altan, E.B., Üçüncüoğlu, I., Öztürk, N. (2019). Preparation of out-of-school learning environment based on science, technology, engineering, and mathematics education and investigating its effects. Science Education International, 30(2): 138-148. https://doi.org/10.33828/sei.v30.i2.7

[10] Yoh, T., Kim, J., Chung, S., Chung, W. (2021). STREAM: A new paradigm for STEM education. Journal of STEM Education, 22(1): 46-51.

[11] Khotimah, R.P., Adnan, M., Ahmad, C.N.C., Murtiyasa, B. (2021). Science, Mathematics, Engineering, and Mathematics (STEM) education in Indonesia: a literature review. In Journal of Physics: Conference Series (Vol. 1776, No. 1). IOP Publishing, pp. 012028. https://doi.org/10.1088/1742-6596/1776/1/012028

[12] Yang, D., Baldwin, S.J. (2020). Using technology to support student learning in an integrated STEM learning environment. International Journal of Technology in Education and Science, 4(1): 1-11. https://doi.org/10.46328/ijtes.v4i1.22

[13] Liu, Z.Y., Lomovtseva, N., Korobeynikova, E. (2020). Online learning platforms: Reconstructing modern higher education. International Journal of Emerging Technologies in Learning, 15(13): 4-21. https://doi.org/10.3991/ijet.v15i13.14645

[14] Decuypere, M., Grimaldi, E., Landri, P. (2021). Critical studies of digital education platforms. Critical Studies in Education, 62(1): 1-16. https://doi.org/10.1080/ $\underline{17508487.2020 .1866050}$ 
[15] Fadzli, S., Yahaya, J., Deraman, A., Hamdan, A.R., Halim, L., Yahaya, N.Z., Zahari, M.S.M., Rais, I.A.I. (2020). Environment based virtual interaction to enhance motivation of STEM education: The qualitative interview design and analysis. Education and Information Technologies, 25(2): 775-790. https://doi.org/10.1007/s10639-019-09996-y

[16] Lin, K.Y., Hsiao, H.S., Chang, Y.S., Chien, Y.H., Wu, Y.T. (2018). The effectiveness of using 3D printing technology in STEM project-based learning activities. EURASIA Journal of Mathematics, Science and Technology Education, 14(12): em1633. https://doi.org/10.29333/ejmste/97189

[17] Lin, K.Y., Lu, S.C., Hsiao, H.H., Kao, C.P., Williams, P.J. (2021). Developing student imagination and career interest through a STEM project using 3D printing with repetitive modeling. Interactive Learning Environments, in press. https://doi.org/10.1080/10494820.2021.1913607

[18] Alabdulhadi, A., Faisal, M. (2021). Systematic literature review of STEM selfstudy related ITSs. Education and Information Technologies, 26: 1549-1588. https://doi.org/10.1007/s10639-020-10315-z

[19] Sirakaya, M., Alsancak Sirakaya, D. (2020). Augmented reality in STEM education: A systematic review. Interactive Learning Environments, in press. https://doi.org/10.1080/10494820.2020.1722713

[20] Voronina, M.V., Tretyakova, Z.O., Krivonozhkina, E.G., Buslaev, S.I., Sidorenko, G.G. (2019). Augmented reality in teaching descriptive geometry, engineering and computer graphics--Systematic review and results of the Russian teachers' experience. EURASIA Journal of Mathematics, Science and Technology Education, 15(12): em1816. https://doi.org/10.29333/ejmste/113503

[21] Kukulska-Hulme, A., Bossu, C., Coughlan, T., Ferguson, R., FitzGerald, E., Gaved, M., Herodotou, C., Rienties, B., Sargent, J., Scanlon, E., Tang, J., Wang, Q., Whitelock, D., Zhang, S. (2021). Innovating Pedagogy 2021: Open University Innovation Report 9. Milton Keynes: The Open University.

[22] Mirapolis Virtual Room (n.d.). Official web site. https://virtualroom.ru/

[23] Moodle (n.d.). Official web site. https://moodle.org

[24] Microsoft Teams (n.d.). Official web site. https://www.microsoft.com/enus/microsoft-teams/group-chat-software

[25] Li, Q., Gross, T.J., McCarroll, P. (2021). Applying the performance pyramid model in STEM education. Journal of STEM Education, 22(1): 25-33.

[26] Baptista, M., Costa, E., Martins, I. (2020). STEM education during the COVID19: Teachers' perspectives about strategies, challenges and effects on students' learning. Journal of Baltic Science Education, 19(6A): 1043-1054. https://doi.org/10.33225/jbse/20.19.1043

[27] Kelley, T.R., Knowles, J.G., Han, J., Trice, A.N. (2021). Integrated STEM models of implementation. Journal of STEM Education, 22(1): 34-45.

[28] Guerrero, S., Crites, T., Hovermill, J., Beaudrie, B. (2018). An innovative STEM education framework for a changing educational landscape. Journal of Curriculum and Teaching, 7(2): 88-98. https://doi.org/10.5430/jct.v7n2p88 
[29] Istrate, O., Mironov, C., Popovici, A. (2019). The use of technology in STEM education: An empirical research. Journal of Pedagogy, 1: 73-91. https://doi.org/10.26755/RevPed/2019.1/73

[30] Akgunduz, D., Mesutoglu, C. (2021). Science, technology, engineering, and mathematics education for industry 4.0 in technical and vocational high schools: Investigation of teacher professional development. Science Education International, 32(2): 172-181. https://doi.org/10.33828/sei.v32.i2.11

[31] Herman, C., Butler, D. (2019). Innovations in STEM distance education. Open Learning: The Journal of Open, Distance and e-Learning, 34(1): 1-5. https://doi.org/10.1080/02680513.2018.1554477

[32] Olson, L. (2021). Teaching innovation. New school staffing strategies inspired by the pandemic. Educational Counsel, Policy, Strategy, Law, Advocacy. https://www.future-ed.org/teaching-innovation-new-school-staffing-strategiesinspired-by-the-pandemic/

[33] Faikhamta, C. (2020). Pre-service science teachers' views of the nature of STEM. Science Education International, 31(4): 356-366. https://doi.org/10.33828/ sei.v31.i4.4

[34] Herranen, J., Fooladi, R.C., Milner-Bolotin, M. (2021). Editorial: Special issue "Promoting STEAM in Education". LUMAT Special Issue, 9(2): 1-8. https://doi.org/10.31129/LUMAT.9.2.1559

[35] Lee, K. (2021). Openness and innovation in online higher education: A historical review of the two discourses. Open Learning: The Journal of Open, Distance and e-Learning, 36(2): 112-132. https://doi.org/10.1080/02680513.2020.1713737

\section{$7 \quad$ Authors}

Menglin Fang is a Postgraduate/PhD, Instructor of the Department of Education, Minxi Vocational \& Technical College, Fujian, China; Lomonosov Moscow State University, Moscow, Russian Federation.

Abdygali Jandigulov is a $\mathrm{PhD}$, Professor of the Department of Algebra and Geometry, L.N. Gumilyov Eurasian National University, Nur-Sultan, Republic of Kazakhstan. Kazakhstan. Email: 661223300230@enu.kz.

Zoya Snezhko is a Senior Lecturer of the Institute of Linguistics and Intercultural Communication, Sechenov First Moscow State Medical University (Sechenov University), Moscow, Russian Federation. Email: snezhko_z_v@staff.sechenov.ru.

Leonid Volkov is a PhD, Associate Professor of the Department of Business Management, Financial University under the Government of the Russian Federation, Moscow, Russian Federation. Email: LVolkov@fa.ru.

Olesya Dudnik is a PhD, Associate Professor of the Department of Sechenov First Moscow State Medical University (Sechenov University), Moscow, Russian Federation. Email: dudnik_o_v@staff.sechenov.ru.

Article submitted 2021-07-03. Resubmitted 2021-08-19. Final acceptance 2021-08-21. Final version published as submitted by the authors. 